\title{
Estimates of genetic parameters for physic nut traits based in the germplasm two years evaluation
}

\author{
Estimativa de parâmetros genéticos de caracteres de pinhão-manso em dois anos de avaliação do banco \\ de germoplasma
}

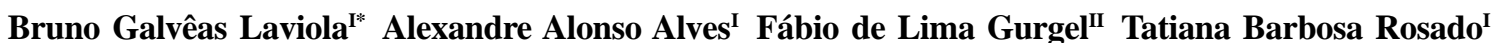 \\ Rodrigo Barros Rocha ${ }^{\mathrm{III}}$ Julio Cesar Albrecht ${ }^{\mathrm{IV}}$
}

\begin{abstract}
In spite of increasingly widespread interest in planting physic nut, breeding efforts are still in its infancy. In that context, an important resource recently established aiming future breeding efforts was the assembly of a germplasm bank with near 200 accessions. The objective of this study was to estimate genetic parameters, repeatibility coefficients and genetic correlation between seven traits, measured in 110 accessions (half sib families) of this germplasm bank in different stages of development. The results show that higher relative values of additive variance were only found for yield and height, and the existence of low environmental variation (either of temporary or permanent nature) among plots within blocks. Given the high repeatibility values found for all traits, on average three measurements are necessary to predict, accurately and efficiently, the true breeding value of an individual. Based on the results of genetic correlations, breeding effort should initially be use track trees with increased stem diameter, elevated number of branches and canopy volume so as to increase the chances of finding an exceptionally highly productive tree.
\end{abstract}

Key words: Jatropha curcas, plant breeding, quantitative genetic.

\section{RESUMO}

Apesar do crescente interesse no plantio do pinhão manso, os esforços de melhoramento ainda estão em seu início. Nesse contexto, um importante recurso recentemente estabelecido visando a futuros trabalhos de melhoramento foi a montagem de um banco de germoplasma com cerca de 200 acessos. O objetivo deste estudo foi estimar parâmetros genéticos, coeficientes de repetibilidade e correlações genéticas entre sete características, mensuradas em 110 acessos (famílias de meios-irmãos) desse banco de germoplasma em diferentes estágios de desenvolvimento. Os resultados demonstram que valores elevados de variância genética aditiva foram encontrados apenas para produção e altura e a existência de baixa variação ambiental (tanto de natureza temporária quanto permanente) entre parcelas dentro de blocos. Dado os altos valores de repetibilidade encontrados para todas as características, em média três mensurações são necessárias para se predizer, acurada e eficientemente, o real valor de melhoramento de um indivíduo. Baseado nos resultados de correlações genéticas, esforços de melhoramento devem inicialmente ser usados para se identificar árvores de elevado diâmetro de caule, elevado número de ramos e volume de copa, de modo a aumentar as chances de se encontrar árvores excepcionalmente produtivas.

Palavras-chave: Jatropha curcas L., melhoramento de plantas, genética quantitativa.

\section{INTRODUCTION}

Physic nut is a perennial shrub of the Euphorbiaceae family. Although it is thought to be native to Central America (FAIRLESS, 2007), it is currently widely dispersed throughout the world. In Brazil, physic nut has been considered as a potential crop to meet the National Program for Production and Use of Biodiesel, recently launched by the Brazilian government (LAVIOLA et al., 2010).

IEmpresa Brasileira de Pesquisa Agropecuária (Embrapa Agroenergia), Parque Estação Biológica, 70770-901, Brasília, DF, Brasil. E-mail: bruno.laviola@embrapa.br. *Autor para correspondência.

IIEmbrapa Amazônia Oriental, Belém, PA, Brasil.

II'Embrapa Rondônia, Porto Velho, RO, Brasil.

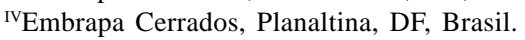


In spite of increasingly widespread interest in planting physic nut (Jatropha curcas L.), there are no elite cultivars available and breeding efforts are still in its infancy. In that context, an important resource recently established aiming future breeding efforts was the assembly of a germplasm bank with near 200 accessions by Embrapa (Brazilian Agricultural Research Corporation) (ROSADO et al., 2010). As this set of accessions effectively constitutes an important initial resource to breeding efforts, an initial characterization of these accessions was made by phenotypically analyzing a number of traits of interest (LAVIOLA et al., 2010; LAVIOLA et al., 2011) and by dissecting it's molecular diversity (ROSADO et al., 2010). The results of both studies indicate that, although limited, there is genetic variability available for breeding purposes in the germplasm currently available in Brazil. However, since the estimated genetic parameters were based in the first production year, there is an urgent need to analyze successive measures in this same group of individuals. The main objectives were to determine the genetic parameters and the repeatibility coefficients for seven traits of interest in mid-stage developing plants based in the germplasm two years evaluation.

\section{MATERIAL AND METHODS}

The experiment was performed with 110 accessions of the physic nut germplasm bank established at the experimental area of the Embrapa Cerrados [Planaltina-DF, Brazil (15³5’30”' south latitude and 4742’30'” west longitude, at $1007 \mathrm{~m}$ altitude)]. The climate in the region is classified according to Köppen-Geiger as Aw, i.e. tropical with dry winter and rainy summer. Temperature ranges from 16.4 to $28.4^{\circ} \mathrm{C}$ (averages of $21.6^{\circ} \mathrm{C}$ and $22^{\circ} \mathrm{C}$, on the first and second year respectively), and the relative humidity from $42.0 \%$ to $91.2 \%$ with averages of $68.0 \%$ and $73 \%$, respectively. Total rainfall in both years was 1012.1 and $1089.4 \mathrm{~mm}$, respectively. The soil is classified as Oxisol with high clay content. For more information on the implementation and management practices (e.g. nutrition, pest and disease control) of the germplasm bank please see DIAS et al. (2007) and LAVIOLA et al. (2010).

The experiment was established using a randomized blocks design with two replicates and five plants per plot arranged in rows (4x2m spacing). Phenotypic evaluations of the 110 accessions were performed considering yield components, agronomic traits and specific descriptors, according to the development of the plants (LAVIOLA et al., 2010). The present work presents the results of the second crop year (November 2009 to July 2010). Data of the first crop year (November 2008 to July 2009), early published by LAVIOLA et al. (2010) was also used in order to estimate the repeatibility coefficients of the traits measured in both rounds and the minimum number of measurements required to correctly determine the breeding value of an individual. The traits that were evaluated twice are (i) grain yield $\left(\mathrm{Y}_{\text {grain }}\right.$, g), (ii) total number of branches per plant (TNB), (iii) plant height (height, $\mathrm{m}$ ), (iv) stem diameter (SD, mm), (v) canopy projection on the row $\left(\mathrm{CP}_{\text {row }}, \mathrm{m}\right)$, (vi) canopy projection between lines $\left(\mathrm{CP}_{\text {between }}, \mathrm{m}\right)$ and (vii) canopy volume $\left(\mathrm{CV}, \mathrm{m}^{3}\right)$. The canopy volume was estimated by approximating the volume of a cylinder with elliptical base (LAVIOLAet al., 2010).

As previously, although belonging to different sampling sites, the progenies were analyzed together, as if it were from the same population. Data analysis was then performed using the statistical model 8 (complete blocks with results per individual) of the software SELEGEN-REML/BLUP (RESENDE \& DUARTE, 2007). The estimates of the genetic parameters $\left[\mathrm{V}_{\mathrm{a}}\right.$ - additive genetic variance; $\mathrm{V}_{\text {plot }}$ environmental variance between plots, $V_{p}$ - variance of the plot permanent effect, $V_{e}$ - temporary residual variance (environmental + non-additive); $\mathrm{V}_{\mathrm{f}}$ - individual phenotypic variance; $h^{2}$ - individual heritability in the restricted sense, i.e. additive effects; $c^{2}{ }_{\text {plot }}$ determination coefficient of plot effect and $c^{2}{ }_{p}$ determination coefficient of permanent effect) and of the individual repeatibility coefficients $(r)$ were obtained based on the following mixed model equation: $y=X_{m}+Z_{a}+W_{p}+T_{s}+e$, where $\mathrm{y}$ is the data vector, $m$ measurement-repetition combination effects (assumed as fixed effects) coupled with the overall mean, $a$ is the vector of individual additive genetic effects (assumed to be random), $p$ is the plot effect vector (assumed to be random), $s$ is the vector of permanent effects (assumed to be random) and $e$ is the vector of errors or residue (random). Capital letters represent the incidences matrices of the referred effects. Individual heritabilities associated with crops means $\left(\mathrm{h}^{2}{ }_{\mathrm{im}}\right)$, genotypic determination coefficients $\left(\mathrm{R}_{\mathrm{g}}^{2}\right)$ and the accuracy of the additive genetic values predicted based on $m_{i}(i=1 \ldots 10)$ measurements, along with the efficiency of these $m_{i}$ measurements when compared with the situation in which only one measurement of the traits is performed, were also calculated. For the analyses of correlations between the genotypic values, SELEGEN-REML/BLUP model 102, which uses standard procedures previously described (RESENDE \& DUARTE, 2007), was adopted. 


\section{RESULTS AND DISCUSSION}

Knowledge on the genetic parameters of economically important traits is essential to predict the expected genetic gains and to guide breeding programs. Such estimates, for a number of physic nut traits, including yield, were first obtained by LAVIOLA et al. (2010) based on the first crop of some of the half-sib families that composes the germplasm bank established by Embrapa. This paper presents genetic parameters based on the results of the first and second crop of the same half-sib families. The variance components and genetic parameters estimates for seven important traits (see methods section for detailed description of the traits) are summarized in table 1 . In general, the higher relative values of additive variance were found for yield and height, a fact that directly reflected on higher individual heritability values in the restricted sense $\left(\mathrm{h}^{2}{ }_{\mathrm{a}}\right)$ (Table 1). Mid-magnitude values of additive genetic variance (0.30-0.60) were found for $\mathrm{SD}, \mathrm{CP}_{\text {row }}, \mathrm{CP}_{\text {between }}$ and VC. However, when considering the variable TNB, it was found that genetic additive variance is quite low, indicating that most of the variability is of environmental nature.

As data from two evaluation rounds (first and second crop) were used, it is also important to consider the variance associated with the plot temporary and permanent effects, as it allows an evaluation of the experimental accuracy. In that respect it can be noted that for the trait that displayed the lowest heritability (TNB) the variances associated with plot and plot permanent effect are quite high, in fact, even higher than the additive genetic variance. This may constitute then complicating factor for selecting the best genotypes considering this trait, since belowaverage genotypes can be selected because permanent environmental effects favored its development over the years, or on the other hand, because the best genotypes (above-average) may not be selected because permanent environmental effects did not favored its development. On the other hand, considering the high heritability traits, e.g. height, these effects are minimal, and most of the variability can be attributed to the genetic effect (Table 1), favoring selection. In order to quantify the variability within blocks the determination coefficient of environmental effects among plots $\left(\mathrm{c}^{2}{ }_{\text {plot }}\right)$ and the determination coefficient of the permanent effect $\left(\mathrm{c}_{\mathrm{p}}^{2}\right)$ were estimated. It was verified that $c^{2}{ }_{\text {plot }}$ and $c^{2}{ }_{p}$ values were low (on average 0.13 and 0.11 , respectively) with an exception being made while considering TNB $\left(\mathrm{c}^{2}{ }_{\text {plot }}\right.$ and $\mathrm{c}^{2}{ }_{\mathrm{p}} \geq 0.2$ - Table 1). These results indicate low environmental variation (of temporary and permanent nature) among plots within the block and low environmental correlation of the observations within plots.

To the best of our knowledge this is the most representative report of the genetic parameters and repeatibility coefficients of numerous morphological traits of cultivated $\boldsymbol{J}$. curcas germplasm in Brazil. Such kind of information may be fundamental

Table 1 - Estimates of genetic parameters, repeatibilities coefficients and general statistics of the grain yield ( $\mathrm{Y}_{\text {grains }}$, grams), total number of branches (TNB), height $(\mathrm{m})$, stem diameter $(\mathrm{SD}, \mathrm{mm})$, canopy projection on the row $\left(\mathrm{CP}_{\text {row }}, \mathrm{m}\right)$, canopy projection between rows $\left(\mathrm{CP}_{\text {between }}, \mathrm{m}\right)$ and canopy volume $\left(\mathrm{CV}, \mathrm{m}^{3}\right)$, measured in 110 accessions of physic nut (Jatropha curcas L.) in two different rounds.

\begin{tabular}{|c|c|c|c|c|c|c|c|}
\hline Parameters & $Y_{\text {grains }}$ & TNB & Height & SD & $\mathrm{CP}_{\text {row }}$ & $\mathrm{CP}_{\text {between }}$ & $\mathrm{CV}$ \\
\hline $\mathrm{V}_{\mathrm{a}}$ & 3381.10 & 0.277 & 0.028 & 63.000 & 0.020 & 0.028 & 0.592 \\
\hline $\mathrm{V}_{\text {plot }}$ & 586.74 & 0.407 & 0.003 & 17.093 & 0.007 & 0.012 & 0.123 \\
\hline $\mathrm{V}_{\mathrm{p}}$ & 20.10 & 0.509 & 0.001 & 16.069 & 0.011 & 0.014 & 0.011 \\
\hline $\mathrm{V}_{\mathrm{e}}$ & 1148.73 & 0.632 & 0.001 & 39.266 & 0.023 & 0.020 & 0.327 \\
\hline$V_{f}$ & 5136.69 & 1.827 & 0.033 & 135.430 & 0.063 & 0.075 & 1.054 \\
\hline$h^{2}{ }_{a}$ & 0.65 & 0.151 & 0.849 & 0.465 & 0.322 & 0.373 & 0.561 \\
\hline$c_{\text {plot }}^{2}$ & 0.11 & 0.223 & 0.107 & 0.126 & 0.125 & 0.164 & 0.116 \\
\hline$c_{p}^{2}$ & 0.01 & 0.279 & 0.023 & 0.118 & 0.185 & 0.192 & 0.010 \\
\hline$R$ & 0.77 & 0.654 & 0.981 & 0.710 & 0.632 & 0.730 & 0.689 \\
\hline Mean $1^{\text {st }}$ crop & 13.77 & 3.69 & 1.35 & 66.01 & 0.88 & 0.89 & 0.87 \\
\hline Maximum $1^{\text {st }}$ crop & 180.86 & 9.00 & 1.87 & 89.49 & 1.66 & 1.97 & 2.71 \\
\hline Minimum $1^{\text {st }}$ crop & 0.00 & 1.00 & 0.72 & 22.01 & 0.40 & 0.44 & 0.17 \\
\hline Mean $2^{\text {nd }}$ crop & 175.82 & 4.50 & 2.41 & 119.79 & 1.20 & 1.27 & 3.05 \\
\hline Maximum $2^{\text {nd }}$ crop & 782.00 & 10.00 & 3.02 & 187.04 & 2.49 & 2.90 & 8.47 \\
\hline Minimum $2^{\text {nd }}$ crop & 51.80 & 1.00 & 1.47 & 69.2 & 0.40 & 0.40 & 0.50 \\
\hline
\end{tabular}

$\mathrm{V}_{\mathrm{a}}$ - additive genetic variance; $\mathrm{V}_{\text {plot }}$ - environmental variance between plots, $\mathrm{V}_{\mathrm{p}}$ - variance of the plot permanent effect, $\mathrm{V}_{\mathrm{e}}$ - temporary residual variance (environmental + nonadditive); $\mathrm{V}_{\mathrm{f}}$ - individual phenotypic variance; $\mathrm{h}_{\mathrm{a}}^{2}$, individual heritability in the restricted sense, i.e. additive effects; $c^{2}$ plot,determination coefficient of plot effect and $c^{2}{ }_{p}$ - determination coefficient of permanent effect and $r$ repeatibility coefficient. 
to direct breeding efforts and the selection strategies to be employed on the breeding populations. Based on the results here presented (estimates of variance components and heritabilities - Table 1), it is clear that the accessions of the germplasm bank possess genetic variability for all traits and that this variability is inherited. As the breeding strategy to be employed on J. curcas improvement will probably rely on intrapopulation recurrent selection and sexual multiplication of the selected genotypes (although clonal propagation is not discarded) the finding of elevated additive genetic variance for numerous traits is encouraging. Given the magnitude of the additive effect measured in many traits it can be speculated that breeding for higher yielding genotypes, or for a given plant architecture is not only possible, but that it could be theoretically easily achievable in initial stages of the breeding program. As Physic nuts have been traditionally cultivated as a hedge plant, with few efforts in selecting plants that yield higher, this may probably be a reflection of the undomesticated behavior of the physic nut accessions (ROSADO et al., 2010). It is notorious that the predicted genetic gains are, most of the times, elevated in the initial stages of a breeding program. In that context, it is noteworthy that the molecular diversity of these accessions seems to be low (ROSADO et al., 2010), in fact lower than phenotypic analysis suggest (LAVIOLA et al., 2010). Other recent reports, sampling diversity with different types of molecular markers have also corroborated that in general there is limited variation in the most accessible germplasm resources of Physic nut in various countries (KUMAR et al., 2009; PAMIDIMARRI et al., 2009). Probably this arise from the fact that neutral molecular markers, such as RAPD or SSR, commonly used in molecular diversity studies, may be located in noncoding regions of the genome (COLLARD et al., 2005), having therefore limited use in predicting the phenotypic diversity of the individuals, especially in complex traits such as yield. In this way, given the relatively narrow genetic basis represented in the germplasm bank, as the selection process proceeds, selection of the best genotypes among good candidates will almost certainly be difficult, and one can predict that the realized gains will probably drop fast after the initial stages of selection. This fact reinforces the need of adding more diversity to the germplasm banks by collecting new samples in the center of origin/diversity of the species as early suggested by ROSADO et al. (2010) and DIVAKARA et al. (2010). These new sources of genetic variability could be later gradually introduced into the base population of the breeding program, so as to assure a wider genetic basis.
An informative comparison can be drawn considering the data here presented and also the data provided by LAVIOLA et al. (2010). It is interesting to note that for some traits, such as height, $\mathrm{SD}, \mathrm{CP}_{\text {row }}$, $\mathrm{CP}_{\text {between }}$ and $\mathrm{CV}$, the individual heritabilities in the restrict sense were increased (some by more than $100 \%$ ), while on the other hand, heritability values of yield and TNB were reduced. Considering that the data gathered by LAVIOLA et al. (2010) was based on phenotypic assessment of very young plants that could be physiologically hampered of expressing all its potential, as here demonstrated by the differences in the general mean, minimum and maximum values for each trait (Table 1), it was foreseeable that genetic parameters based on older plants would differ from those obtained with young plants. RESENDE et al. (2001), also acknowledge that in studies using perennial plants, the individual coefficient of heritability might be inflated by the interaction genotypes $\mathrm{x}$ years. By removing the permanent environmental effects and by assessing the phenotypes in adequate ages, successive measurements over time seems then to offer some advantages over one measurement taken very early. Taken together these results corroborate the need of assessing the plants phenotypes at older ages, preferably in sequential measurements (minimum number discussed below) in order to obtain conclusive results on the estimates of the genetic parameters of many important traits.

In perennial species, it is expected that the initial superiority after selection of a certain genotype would persist throughout the cycle. The measure of consistency of the relative position of the trees during successive measurements has traditionally been called repeatibility. Here high repeatibility coefficients are reported for all evaluated traits (Table 1), a fact that may indicate that the phenotype of a given individual can be correctly assessed with a minimal number of measurements. Indeed considering a genotypic determination coefficient (that represents the degree of certain on the prediction of the true value of an individual based on $m$ measurements $-\mathrm{R}_{\mathrm{g}}^{2}$ ) of 0.85 or higher, on average three (2.71) measurements are necessary (Table 2) to predict the true value of an individual for all traits. It is interesting to note that, the selection based on three measurements rounds would, in theory, be accurate (accuracy of 0.74 , on average) and that the gain of efficiency with this strategy, when compared to selection based on one measurement, would be of $10 \%$, on average. It is also noteworthy, that TNB and SD would be the more benefited traits, with a gain of efficiency of 14 and $17 \%$ (Table 2). On the other hand, as the repeatibility of height measurements is elevated, it is not necessary to 
evaluate this trait more than once, as the values of accuracy and efficiency virtually do not vary, regardless of the number of measurements (Table 2). Another desirable result of performing three measurements instead of one is that the individual heritabilities associated with crop means $\left(\mathrm{h}^{2}{ }_{\mathrm{im}}\right)$ are also increased by $22 \%$ on average (Table 2 ).

Knowledge of the association between traits is of great importance to the selection practice in breeding programs, as it may allow indirect gains to be obtained, contributing at the same time to maintain the genetic variability of non-selected traits. Table 3 presents the estimates of genotypic correlations among the seven measured traits. Higher magnitude correlations were observed for characters that have a direct relationship, e.g. canopy traits, a fact that was obviously expected. Correlations of medium to low magnitude, however, were observed for all other traits (Table 3). It is interesting to note that a correlation of medium magnitude was obtained between height and yield. As the individual heritability in the restricted sense and the repeatibility coefficient of height is

Table 2 - Individual heritabilities associated with crops means $\left(\mathrm{h}^{2}{ }_{\mathrm{im}}\right)$, genotypic determination $\left(\mathrm{R}_{\mathrm{g}}^{2}\right)$ and the accuracy of the additive genetic values predicted based on $m$ measurements, along with the efficiency of these $m$ measurements when compared with the situation in which only one measurement.

\begin{tabular}{|c|c|c|c|c|c|c|}
\hline Variables* & Parameters/N. of Measurements & 1 & 2 & 3 & 4 & 5 \\
\hline \multicolumn{7}{|l|}{$Y_{\text {grains }}$} \\
\hline & $\mathrm{h}_{\mathrm{im}}^{2}$ & 0.65 & 0.74 & 0.77 & 0.79 & 0.80 \\
\hline & $\mathrm{R}_{\mathrm{g}}^{2}$ & 0.77 & 0.87 & 0.91 & 0.93 & 0.94 \\
\hline & Accuracy & 0.81 & 0.86 & 0.87 & 0.88 & 0.89 \\
\hline & Efficiency & 1.00 & 1.06 & 1.08 & 1.09 & 1.10 \\
\hline \multicolumn{7}{|l|}{ TNB } \\
\hline & $\mathrm{h}_{\mathrm{im}}^{2}$ & 0.15 & 0.18 & 0.19 & 0.20 & 0.20 \\
\hline & $\mathrm{R}_{\mathrm{g}}^{2}$ & 0.65 & 0.79 & 0.85 & 0.88 & 0.90 \\
\hline & Accuracy & 0.38 & 0.42 & 0.44 & 0.45 & 0.45 \\
\hline & Efficiency & 1.00 & 1.09 & 1.14 & 1.16 & 1.17 \\
\hline \multicolumn{7}{|l|}{ Height } \\
\hline & $\mathrm{h}_{\mathrm{im}}^{2}$ & 0.84 & 0.85 & 0.86 & 0.86 & 0.86 \\
\hline & $\mathrm{R}_{\mathrm{g}}^{2}$ & 0.98 & 0.99 & 0.99 & 0.99 & 0.99 \\
\hline & Accuracy & 0.92 & 0.92 & 0.92 & 0.92 & 0.92 \\
\hline & Efficiency & 1.00 & 1.004 & 1.006 & 1.007 & 1.007 \\
\hline \multicolumn{7}{|l|}{ SD } \\
\hline & $\mathrm{h}_{\mathrm{im}}^{2}$ & 0.46 & 0.54 & 0.57 & 0.59 & 0.60 \\
\hline & $\mathrm{R}_{\mathrm{g}}^{2}$ & 0.71 & 0.83 & 0.88 & 0.90 & 0.92 \\
\hline & Accuracy & 0.68 & 0.73 & 0.75 & 0.77 & 0.77 \\
\hline & Efficiency & 1.00 & 1.08 & 1.11 & 1.13 & 1.14 \\
\hline \multicolumn{7}{|l|}{$\mathrm{CP}_{\text {row }}$} \\
\hline & $\mathrm{h}_{\mathrm{im}}^{2}$ & 0.32 & 0.39 & 0.42 & 0.44 & 0.45 \\
\hline & $\mathrm{R}_{\mathrm{g}}^{2}$ & 0.63 & 0.77 & 0.83 & 0.87 & 0.89 \\
\hline & Accuracy & 0.56 & 0.62 & 0.65 & 0.66 & 0.67 \\
\hline & Efficiency & 1.00 & 1.10 & 1.15 & 1.17 & 1.18 \\
\hline \multicolumn{7}{|l|}{$\mathrm{CP}_{\text {between }}$} \\
\hline & $\mathrm{h}_{\mathrm{im}}^{2}$ & 0.37 & 0.43 & 0.45 & 0.46 & 0.47 \\
\hline & $\mathrm{R}_{\mathrm{g}}^{2}$ & 0.73 & 0.84 & 0.89 & 0.91 & 0.93 \\
\hline & Accuracy & 0.61 & 0.65 & 0.67 & 0.68 & 0.69 \\
\hline & Efficiency & 1.00 & 1.07 & 1.10 & 1.11 & 1.12 \\
\hline \multicolumn{7}{|l|}{$\mathrm{CV}$} \\
\hline & $\mathrm{h}_{\mathrm{im}}^{2}$ & 0.56 & 0.66 & 0.70 & 0.73 & 0.74 \\
\hline & $\mathrm{R}_{\mathrm{g}}^{2}$ & 0.68 & 0.81 & 0.86 & 0.89 & 0.91 \\
\hline & Accuracy & 0.74 & 0.81 & 0.84 & 0.85 & 0.86 \\
\hline & Efficiency & 1.00 & 1.08 & 1.12 & 1.14 & 1.15 \\
\hline
\end{tabular}

${ }^{*}$ Grain yield ( $\mathrm{Y}_{\text {grains }}$, grams), total number of branches (TNB), height (m), stem diameter (SD, mm), canopy projection on the row (CP ${ }_{\text {row }}$, $m$ ), canopy projection between rows $\left(\mathrm{CP}_{\text {between }}, \mathrm{m}\right)$ and canopy volume $\left(\mathrm{CV}, \mathrm{m}^{3}\right)$. 
Table 3 - Genetic correlations between grain yield ( $\mathrm{Y}_{\text {grains, }}$ grams), total number of branches (TNB), height (m), stem diameter (SD, mm), canopy projection on the line $\left(\mathrm{CP}_{\text {row }}, \mathrm{m}\right)$, canopy projection between rows $\left(\mathrm{CP}_{\text {between }}, \mathrm{m}\right)$, canopy volume $\left(\mathrm{CV}, \mathrm{m}^{3}\right)$, number of days to flowering (NDF) and height of the first inflorescence (HFI, m), in the analysis of second crop of 110 accessions of physic nut (Jatropha curcas L.).

\begin{tabular}{|c|c|c|c|c|c|c|c|}
\hline & $Y_{\text {grains }}$ & TNB & Height & SD & $\mathrm{CP}_{\text {row }}$ & $\mathrm{CP}_{\text {between }}$ & $\mathrm{CV}$ \\
\hline$Y_{\text {grains }}$ & 1.0000 & $0.3122 * *$ & $0.2928 * *$ & $0.3184^{* *}$ & $0.5129 * *$ & $0.5636 * *$ & $0.5578 * *$ \\
\hline TNB & & 1.0000 & $-0.1069^{\mathrm{ns}}$ & $0.4281^{* *}$ & $0.4391^{* *}$ & $0.4882^{* *}$ & $0.3248^{* *}$ \\
\hline Height & & & 1.0000 & $0.4479 * *$ & $0.3511 * *$ & $0.3181^{* *}$ & $0.5110 * *$ \\
\hline SD & & & & 1.0000 & $0.5419 * *$ & $0.5499 * *$ & $0.5314^{* *}$ \\
\hline $\mathrm{CP}_{\text {row }}$ & & & & & 1.0000 & $0.8739 * *$ & $0.9257^{* *}$ \\
\hline $\mathrm{CP}_{\text {between }}$ & & & & & & 1.0000 & $0.9214^{* *}$ \\
\hline CV & & & & & & & 1.0000 \\
\hline
\end{tabular}

**Significant at $1 \%$ by $t$ test, respectively; ns, not significant.

higher than those same parameters of yield, on a first moment, i.e. initial stages of Jatropha breeding programs, more productive plants could be potentially tracked based on its height. However, one has to concomitantly consider the canopy volume and total number of branches, as these traits shows a positive significant correlation with yield. Significant genetic correlations between stem diameter (SD) and TNB (0.428) and SD with yield $(0,3184)$ were also observed (Table 3). As these are important components of yield (LAVIOLA et al., 2010), perhaps then, instead of performing pre-selection solely based on plant height, breeders could track trees with increased stem diameter, elevated number of branches and increased canopy volume so as to increase the chances of finding a highly productive tree (high yield).

Thus, the understanding of the genotypic correlations among physic nut characters is important for a breeding program, especially in defining the criteria for selection of characters of economic importance as well as for the construction of selection indexes for multi-traits (LAVIOLAet al., 2010; SPINELLI et al., 2010). In that respect, it is interesting to note that as physic nut produces inflorescences in the terminal buds of the branches grown in the current year, yield is expected to be highly dependent on the TNB (LAVIOLA et al., 2011). These authors, however, notice that with the data of the first crop there was a low genetic correlation of TNB with grain production (0.131). They argued that the age when plants were phenotyped could have interfered in the results, as it is likely that in the first year, competition for photoassimilates and nutrients occurs. Here it was shown that the genetic correlation between TNB and yield was increased to 0.312, further suggesting that phenotyping early developing plants do not correctly assess its potential. Other possible indicators of the plants potential may be stem diameter and canopy volume, as in other perennial species, SD and CV have been shown to be genetically correlated with yield and its components (SPINELLI et al., 2010). Indeed the correlation between SD and yield (0.3184) is of the same magnitude as the correlation of TNB and yield, while CV was one of the traits that had the highest correlation with yield (0.557). Canopy volume for its turn is directly implicated in the amount of photoradiation intercepted by the leaves, and thus with photosynthesis. However, as CV correlation with canopy projection between rows is high (0.9214) and because $\mathrm{CP}_{\text {between }}$ also correlates well with yield ( 0.5636$)$, it seems reasonable that instead of measuring canopy projection on the row canopy projection between rows, so as to calculate canopy volume, one only measure $\mathrm{CP}_{\text {between }}$ The data here presented then suggest that if the objective is to track down exceptional trees in the initial stages of the breeding program breeders should try to identify plants with increased stem diameter, elevated number of branches and increased canopy volume.

As the results of this paper clearly demonstrate the existence of genotypic variability for numerous traits of interested, and that accurate selection can be performed based on a minimum of three evaluations, a last important issue to consider is what to look for. However, during the three years period (in which the measurements take place) breeders could use information regarding genetic correlations to track down some exceptional plants that potentially yield higher to be cloned (propagation via mini-cuttings is being currently tested) and latter deployed. In that context, knowledge on the values of genetic correlations have been used to guide breeding programs, since they reflect the fraction of the phenotypic expression of two characters which is coinheritable in nature (RESENDE, 2002). 


\section{CONCLUSION}

Estimates of genetic parameters of vegetative characters evaluated in 110 accessions of physic nut during the first and second year of development revealed genetic variability suitable for a breeding program, providing high selection efficiency.

Based on the results of genetic correlations, breeding effort should initially be use track trees with increased stem diameter, elevated number of branches and canopy volume so as to increase the chances of finding an exceptionally highly productive tree.

\section{ACKNOWLEDGMENTS}

To Financiadora de Estudos e Projetos (FINEP) and Conselho Nacional de Desenvolvimento Científico e Tecnológico (CNPq) for funding the BRJATROPHA research project and Julio Cesar Marana, Laise Teixeira da Costa and Genivaldo Jose Fonseca, Embrapa Agroenergia staff members, for their dedication in conducting the work of crop management and morpho-agronomic evaluation of the acessions form the germplasm bank.

\section{REFERENCES}

COLLARD, B.C.Y. et al. An introduction to markers, quantitative trait loci (QTL) mapping and marker-assisted selection for crop improvement: the basic concepts. Euphytica, v.142, p.169-196, 2005. Available from: <http:// www.springerlink.com/content/u47140m3806j7772/>. Accessed: Nov. 19, 2011. doi: 10.1007/s10681-005-1681-5.

DIAS, L.A.S. et al. Cultivo de pinhão manso (Jatropha curcas $L$.) para produção de óleo combustível. Viçosa, MG: edição do autor, 2007. 40p.

DIVAKARA, B.N. et al. Biology and genetic improvement of Jatropha curcas L.: a review. Applied Energy, v.87, p.732 742, 2010. Available from: <http://www.sciencedirect.com/ science/article/pii/S030626190900302X>. Accessed: Nov. 19, 2011. doi: 10.1016/j.apenergy.2009.07.013.

FAIRLESS, D. Biofuel: The little shrub that could - maybe. Nature, v.449, p.652-655, 2007. Available from: <http:// u k p m c . a c . u k/ a b s t r a c t / M E D / 17968401 / reload=0; jsessionid=841455C2209DE4E3D82A3CF6AF2D4367 > . Accessed: Nov. 19, 2011. doi: 10.1038/449652a.

KUMAR, R.V. et al. Genetic diversity and relationships among germplasm of Jatropha curcas L. revealed by RAPDs. Trees-
Structure and Function, v.23, p.1075-1079, 2009. Available from: <http://www.springerlink.com/content/288167727tl0u131/> Accessed: Nov. 19, 2011. doi: 10.1007/s00468-009-0350-z.

LAVIOLA, B.G. et al. Genetic parameters and variability in physic nut accessions during early developmental stages. Pesquisa Agropecuária Brasileira, v.45, p.1117-1123, 2010. Available from: <http://www.scielo.br/scielo.php?pid=S0100204X2010001000010\&script $=$ sci_arttext\&tlng=pt $>$. Accessed: Nov. 19, 2011. doi: 10.1590/S0100-204X2010001000010.

LAVIOLA, B.G. et al. Caracterização morfo-agronômica do banco de germoplasma de pinhão-manso na fase jovem. Bioscience Journal, v.27, p.371-379, 2011. Available from: <http://www.seer.ufu.br/index.php/biosciencejournal/article/ view/7651>. Accessed: Nov. 19, 2011.

PAMIDIMARRI, D.V.N.S. et al. Molecular characterization and identification of markers for toxic and non-toxic varieties of Jatropha curcas L. using RAPD, AFLP and SSR markers. Molecular Biology Reports, v.36, p.1357-1364, 2009. Available from: <http://www.springerlink.com/content/ 32163012u767wh32/>. Accessed: Nov. 19, 2011. doi: 10.1007/ s11033-008-9320-6.

RESENDE, M.D.V.; DUARTE, J.B. Precisão e controle de qualidade em experimentos de avaliação de cultivares. Pesquisa Agropecuária Tropical, v.37, p.182-194, 2007. Available from: <http://www.revistas.ufg.br/index.php/pat/article/view/ 1867>. Accessed: Nov. 19, 2011.

RESENDE, M.D.V. Genética biométrica e estatística no melhoramento de plantas perenes. Brasília, DF: Embrapa Informação Tecnológica, 2002. 975p.

RESENDE, M.D.V. et al. Estimativas de parâmetros genéticos e predição de valores genotípicos no melhoramento do cafeeiro pelo procedimento Reml/Blup. Bragantia, v.60, p.185-193, 2001. Available from: <http://www.scielo.br/ s c i e l o.ph p ? s c ri p t = s c i _ p d f \& pi d = S 0006 87052001000300005\&lng=pt\&nrm=iso\&tlng=pt>. Accessed: Nov. 19, 2011.

ROSADO, T.B. et al. Molecular markers reveal limited genetic diversity in a large germoplasm collection of the biofuel crop Jatropha curcas L. in Brazil. Crop Science, v.50, p.1-11, 2010. Available from: <http://www.alice.cnptia.embrapa.br/ handle/doc/864160>. Accessed: Nov. 15, 2011 doi: 10.2135/ cropsci2010.02.011.

SPINELLI, V.M. et al. Primary and secondary yield components of the oil in physic nut (Jatropha curcas L.). Ciência Rural, v.40, p.1752-1758, 2010. Available from: <http://www.scielo.br/ pdf/cr/v40n8/a687cr3156.pdf>. Accessed: Nov. 19, 2011. 